\title{
Impact of Audit Committee structure on firms' value in Pakistan: Evidence from the Cement Sector
}

\author{
Kamran $\mathrm{Ali}^{1}$ \& Muhammad Amir, ${ }^{1, *}$ \\ ${ }^{1}$ Dept. of Business Administration, University of the Punjab, Gujranwala Campus, Pakistan \\ *Correspondence: Dept. of Business Administration, University of the Punjab, Gujranwala \\ Campus, Pakistan. Tel: 92-320-609-6074. E-mail: ma.arain824@gmail.com
}

Received: June 2, 2018 Accepted: August 2, 2018 Published: November 20, 2018

doi: 10.5296/jcgr.v2i1.14028 URL: https://doi.org/10.5296/jcgr.v2i1.14028

\begin{abstract}
The core tenacity of this study is to check out how the audit committee structure influence on firms' financial value. With the help of literature, the study sets its main objective and uses penal data of 14 companies from cement sector which covers a period of 4 years from 2013 to 2016. The fixed effect approach is used to get the results of regression. The finding of the empirical outcomes is indicating that the Audit Committee structure has a substantial effect on firms' financial value. The study used data from one sector and only from Pakistan, due to which the application of results in other sectors and the economy is not strong enough. According to superlative of our understanding, this type of research has conducted for the first time in Pakistan which contributes in the fiction of corporate governance as a showing effect of the audit committee structure on firms' performance. This article provides helpful information to those who are affiliated with the management authorities when they design the structure of Audit committee, so they should make a good combination of audit committee elements for the better performance of the company.
\end{abstract}

Keywords: audit committee, AC structure, cement sector, Tobin's Q, company performance 


\section{Introduction}

The core tenacity of this research is to find out how the audit committee (AC) structure influence performance of the company. In prior studies, there is a lot of inquiries on AC and its structure is available, and their influence has been tested with company performance, the company reporting writing process, company disclosure etc. (Aldamen, Duncan, Kelly, McNamara, \& Nagel, 2012). Audit committee is considered to be one of the keys and persuasive players in CG helps the director of the board in fulfilling their responsibilities by managing the company administration (Bédard \& Gendron, 2010; Li, Mangena, \& Pike, 2012).

An audit committee (AC) is a committee that looks at the various types of decisions and activities performed by corporate executives and management. Audit Committee (AC) works for shareholder's interest, by giving different independent reviews and objections on company executives and management decisions to reduce the frauds and agency conflict (Fama \& Jensen, 1983; Klein, 1998). The researcher checks the impact of AC with three magnitudes: AC size, AC meeting frequency, and the percentage of the independent auditors in AC (Berkman \& Zuta, 2017). And the financial performance of the companies is measured as Tobin's Q (Agyemang-Mintah, 2015; Agyemang-Mintah \& Schadewitz, 2018; Berkman \& Zuta, 2017; Black, Jang, \& Kim, 2006).

In the context of Pakistan, there are some studies existing related to $\mathrm{AC}$ and its structure, so it is the motivation factor for the researcher to donate in the literature of $\mathrm{AC}$ in the viewpoint of Pakistan. The first motivation for the researcher is to contribute to AC literature. Secondly, $\mathrm{AC}$ is the only committee which controls and make objections on corporate decision for the interest of shareholders. Third one is, the empirical research on cement sector in Pakistan that is very rare and erratic. So this research makes a valuable contribution to the cement sector as well as literature of AC in Pakistan.

The researcher completes his research work in the following remaining sections: the second section is related to the background literature and hypothesis development to support the research tenacity. Third section, is based on research methodology, testing of the hypothesis and measurement of the variables, also generate a regression model of study. Forth section is linked to the analysis of the regression and discussion about the descriptive results, empirical results, and the hypothesis. Fifth section is interconnected to the summary and conclusion of the research, also discuss the research limitations and provide some sanctions for assisting research.

\section{Literature Review and Hypothesis Development}

The place of AC under the main board of directors. The BOD has given the authority to AC to look into the company's reporting process (Bédard \& Gendron, 2010; Li et al., 2012). The committee is such a device that eliminates the intervention of publishing the company's information (Akhtaruddin \& Haron, 2010) and aids soften the agency costs in the company (Bédard \& Gendron, 2010). All this indicate us that AC is a source of monitoring and 
improving the company's system (Akhtaruddin \& Haron, 2010; Barako, Hancock, \& Izan, 2006; Bédard \& Gendron, 2010) including company reporting and publication process.

Studies in the past on audit committee show the effectiveness of AC is the function of its structure (Dhaliwal, Naiker, \& Navissi, 2010; Li et al., 2012; Persons, 2009). Hence, the perfect mishmash of experience and skill helps AC to fulfill its responsibilities in the best way. So we can say there is a connection between AC structure and the firms' value (Madi, Ishak, \& Manaf, 2014).

So our tenacity is to know what the impact of AC's structure on the firms' value (Ferreira, 2008). To accomplish this objective, we studied various types of papers related to audit committee, its structure (i.e. AC's size, AC's meeting frequency, AC's independence, etc.) and company's performance.

There were various types of results after various studies, from a study it came to know that if AC's size is smaller and members experience is high then it is positively associated with the company's performances. And as well, if the chairman seat is too long in AC, it negatively associates with a company's accounting performance (Aldamen et al., 2012). A study finds that $\mathrm{AC}$ with autonomous members is more efficient to prevent frauds in the company as compared to AC with internal members (Abbott, Park, \& Parker, 2000). A study indicates that the AC's size, independence, and the directorship of AC's members at multiple boards is positively related to the company reporting process and performance. However, the meeting frequencies of $\mathrm{AC}$ and members experience is not significantly related to the firms' value and the disclosure of reporting (Madi et al., 2014).

From a study, it also shows that there is a good system of AC, members' forecasting is more update and more accurate which is likely to be according to the market response, so for the better performance the AC structure having valuable consideration (Karamanou \& Vafeas, 2005). A study also states that an independent AC charge higher fee for high slandered of quality in the reporting process of the company(Carcello, Hermanson, Neal, \& Riley, 2002). In a similar study, the researcher says positive association between the reporting process of the company and independent AC (Carcello \& Neal, 2003; Felo, Krishnamurthy, \& Solieri, 2003).

A study in Pakistan shows the positive relationship between ROE and AC in oil and gas sector (Arslan, Zaman, Malik, \& Mehmood, 2014). Another study indicates the positive association between AC members and firms value companies listed in Pakistan stock exchange (Qaiser Rafique \& Al Mamun, 2015) A study in Singapore argues that the members of the ACs, who are more autonomous, provide better and effective results (Van Der Zahn \& Tower, 2004). A research indicates the AC which has more members and its members has different types of professional knowledge, provides better and effective outcomes (Choi, Jeon, $\&$ Park, 2004). The researcher perceived that the newly appointed 850 outside directors during 1993 and 2002 in AC having a progressive and significant influence on the firms' value (DeFond, Hann, \& Hu, 2005). By using a sample of companies from 2002 to 2004 after the COC released by the Chinese supervisory authority the researcher establish the positive effect of AC on a company's financial performance (Zha, 2006). A research in Sub Saharan, 


\section{Ml Macrothink}

Journal of Corporate Governance Research ISSN 1948-4658 2018, Vol. 2, No. 1

African countries argues that there is a progressive and noteworthy link between AC and firms' value (Munisi \& Randøy, 2013).

On the other hand, there is a lot of benefits with the help of AC can be achieved, some studies specify the manifestation of AC either having no effect or negatively associated with firms' value. An Italian study indicates that the meeting frequency of insider ownership is adversely associated with the performance of the board while the outsider members are positively associated with the performance (Greco, 2011). An India-based research that compiled the data of 317 companies from 2008 to 2012, independent AC has an adverse influence on firms' value (Khosa, 2017). Another research state the adverse link between AC size and the firms' value (Bradbury, Mak, \& Tan, 2006). A research on US industries shows the negative relationship between the AC board and the firms' value (Yermack, 1996).

There are more or fewer revisions, which argue there is no noteworthy link between the firms' value and AC. A research conduct by Rahman and Ali find no significant association in AC and earning management (Abdul Rahman \& Haneem Mohamed Ali, 2006). The reason is that the directors did not pay their duty due to management intervention.

\subsection{Hypothesis Development}

After collecting various types of research evidence, the prediction of this study is that the AC structure can have any a progressive or adverse link with the company's performance. Hereafter, the following hypothesis is developed for testing to get the study results:

$H_{1}:$ There is a postive reletionship between AC.SIZE and company's performance

$H_{2}$ :There is a postive reletionship between AC.MF and company's performance

$H_{3}:$ There is a postive reletionship between AC.Ind.A. and company's performance

\section{Research Methodology}

\subsection{Research Sample}

This study uses the data of 14 Pakistani companies from the cement sector and covers a 4-year period from 2013 to 2016, data manually obtained from the annual publications of the companies. The decision to use the annual publications is trustworthy with previous research revisions. e.g., (Agyemang-Mintah, 2015; Botosan, 1997; Chenhall \& Moers, 2007; Ho \& Williams, 2003; Mangena \& Chamisa, 2008; Ntim, 2013; Zagorchev \& Gao, 2015).

The annual publications of 14 companies generate 56 observations, which are satisfactory to aid in the testing of hypostasis and added a significant input in AC literature. Due to time limitation, the researcher uses a small sample for the research process. But it does not mean that sample is insufficient, many other studies, a similar range of the sample, for example, a study in Nigeria used 25 company's data for its research purpose (Aanu, Odianonsen, \& 


\section{$\Lambda$ Macrothink}

Journal of Corporate Governance Research ISSN 1948-4658

Foyeke, 2014). A researcher used only 36 annual reports for his research process (Firer \& Meth, 1986), while this research used 56 annual reports. Another study related to use 20 annual reports for its research process on mining companies (April, Bosma, \& Deglon, 2003). However, it does not indicate that for a significant research a small size of data is sufficient. The researcher suggests more significant results; the sample size should be increased. But this research has been done with small sample size due to time limitation.

\subsection{Research Variables}

This research uses three types of the variable for testing of hypothesis and obtains results to answer the research objective. The following three types of variables discussed in details below:

\subsubsection{Dependent Variable}

In this study, the firms' value is a dependent variable which is measured by Tobin's Q which is used to represent the financial valuation of the companies. In many prior studies, it has been used for the company's financial performances. E.g., (Agrawal \& Knoeber, 1996; Beiner, Drobetz, Schmid, \& Zimmermann, 2006; Black et al., 2006; Gompers, Ishii, \& Metrick, 2003; Guest, 2009; Haniffa \& Hudaib, 2006; Henry, 2008; Klapper \& Love, 2004; Krause \& Tse, 2016; Yermack, 1996). Tobin's Q is calculated as total assets - MVE +BE / entire assets (Beiner et al., 2006; Chung \& Pruitt, 1994).

\subsubsection{Independent Variable}

In this research 3 independent variable are used, jointly name is AC's structure. The first one is AC Size, which is the sum of AC members. The second one is AC's M.F, which is the frequency of the meeting held by $\mathrm{AC}$ in a year. And the third one is AC Ind.A., which is the ratio of independent members of the AC (Abbott et al., 2000; Aldamen et al., 2012; Berkman \& Zuta, 2017).

\subsubsection{Control Variables}

To check the relationship between dependent and independent variables some control variables also introduce in the model in order to diminish the omitted bias of potential variables. So with the help of literature, these are the control variable, related to our model, added in this research regression. First one is GROWTH, companies which have more opportunities for investments they known as faster growing companies due to this their valuation and performance is better in the future. Growth is premeditated by the total sale growth ratio divided by total assets growth (Durnev \& Kim, 2005; Klapper \& Love, 2004). Second, one LEV., which is the capital structure because it has a great effect on the company's profit. It is calculated as company total debts divide by total assets (Modigliani \& Miller, 1963). The third one is FSIZE, which is calculated by the neutral log of company total assets (Waresul Karim, van Zijl, \& Mollah, 2013).The fourth one is the BIG4, it is a dummy variable. A company audited by big four audit companies in Pakistan is getting 1 , else 0 (Agyemang-Mintah \& Schadewitz, 2018).

All independent, control and dependent variable define more clearly in "figure 1" in the 
appendix.

\subsubsection{The Regression Model}

With the help of literature review and measurement of variables, the researcher designs the following regression model to testing the hypothesis and answer the objectives of the revision:

$$
\text { Tobin's } Q_{i_{a}, t}=\alpha_{0}+\sum_{i=1}^{n=3} \alpha_{i} \text { AC.Structure } e_{i, t}+\sum_{j=1}^{n=4} \beta_{j} \text { Controls }_{i, t}+\varepsilon_{i, t}
$$

In the regression model, the performance of the companies measured with the help of Tobin's $\mathrm{Q}, \boldsymbol{\alpha}_{0}$ is the constant, $\boldsymbol{\alpha}_{i}$ is the AC Structure, which is the sum of all independent variable including $\mathrm{AC}$ Size, AC. MF, AC \%ind. $\mathrm{A}$ and $\beta_{j}$ is the sum of all control variables including GROWTH, LEV (capital structure), C.SIZE (company size), and Big4 (big four auditing firms for external audit). The last is the error term for company $i$ at time $t$ in the model.

\section{Analysis of Data}

\subsection{Descriptive Results}

Table 1. Descriptive Statistics for All Variables

\begin{tabular}{lccccc}
\hline & Count & Minimum & Maximum & Mean & S.D \\
\hline Tobin's Q & 56 & 1 & 3 & 1.39 & .528 \\
AC-Size & 56 & 3 & 6 & 3.80 & .923 \\
AC-MF & 56 & 4 & 7 & 4.41 & .654 \\
IND-A & 56 & 0 & 100 & 34.68 & 23.718 \\
Growth & 56 & -30 & 54 & 1.34 & 9.036 \\
LEV & 56 & 0 & 4 & .32 & .664 \\
C-Size & 56 & 22 & 25 & 23.34 & .978 \\
Big4 & 56 & 0 & 1 & .77 & .426 \\
N & 56 & & & & \\
\hline
\end{tabular}

Table 1 designates the full statistics description of all study variables which are used in the empirical test of the research study. The descriptive statistics indicates the variation of study variables, which defines the study normality and distribution of all the variables, many researchers include it in their research studies like (Beiner et al., 2006; Guest, 2009; Henry, 2008; Ntim, 2013). Descriptive statistics provide help to explain variable in that way, for example, the minimum value of Tobin's Q is 1 and maximum is the 3 whereas mean is 1.39 and the standard deviation is the 0.528 which indicate the wide variation from mean to plus \& 
minus (Ntim, 2013).

\subsection{Multicollinearity Test}

When all the independent variables are very much correlated with the dependent variable, a problem of multicollinearity are occurred (Klein, 1998; Waresul Karim et al., 2013). In this condition it creates instability in regression results, therefore there is a requisite to control it. In any pairs of two expounding variables the correlation should not be high then 0.80 (Hair, Black, Babin, Anderson, \& Tatham, 1998). The researcher uses person correlation in the study for checking the multicollinearity and no high correlation is found. See table 2 which show the multicollinearity absence in the study (Agyemang-Mintah \& Schadewitz, 2018; Hair et al., 1998; Waresul Karim et al., 2013). For example, AC size positive and significantly correlated with (Tobin's Q) firms' value (Agyemang-Mintah \& Schadewitz, 2018).

Table 2. Person Correlation Matrix

\begin{tabular}{ccccccccc}
\hline Correlation & TOBIN_S_Q & AC_MF & AC_SIZE & \%IND_A & GROWTH & LEV & C_SIZE & BIG4 \\
\hline TOBIN_S_Q & 1.000000 & & & & & & & \\
AC_MF & 0.123313 & 1.000000 & & & & & & \\
AC_SIZE & 0.363619 & 0.045698 & 1.000000 & & & & & \\
IND_A & -0.064705 & -0.196503 & -0.169586 & 1.000000 & & & & \\
GROWTH & -0.131183 & -0.077849 & -0.247393 & -0.014403 & 1.000000 & & & \\
LEV & -0.191294 & -0.139619 & -0.026412 & 0.271268 & 0.047963 & 1.000000 & & \\
C_SIZE & 0.192861 & 0.304566 & 0.277144 & -0.609616 & -0.179242 & -0.309143 & 1.000000 & \\
BIG4 & 0.437671 & 0.217778 & 0.251881 & 0.141290 & -0.376839 & -0.011193 & 0.122766 & 1.000000 \\
\hline
\end{tabular}

\subsection{Empirical Results}

The main motivational tenacity of the revision is to check the effect of AC structure on a company's financial performance. A different analysis is used by prior studies to check the effect of independent variables on dependent variables in term of simple LSL, multiple regression, fixed approach or random approach (Agyemang-Mintah \& Schadewitz, 2018; Mousa \& Saeed, 2017; Othman, Ishak, Arif, \& Aris, 2014). On the basis of literature and according to data style the researcher first runs a houseman test to decide either regression analysis with the fixed approach is appropriate or with the random approach.

\section{Housman test:}

The researcher develops the hypothesis about the housemen test to decide which regression analysis model is best to check the effect:

\section{$H_{0}:$ Random effect model is appropriate}




\section{$H_{A}$ : Fixed effect model is appropriate}

\begin{tabular}{lrrc}
\hline Test Summary & Chi-Sq. Statistic & Chi-Sq. d.f. & Prob. \\
\hline Cross-section random & 20.954919 & 7 & 0.0038 \\
\hline
\end{tabular}

The result of the housemen test indicates that we reject $\mathrm{H}_{0}$. Because the probability value of housemen test is less the $5 \%$ or 0.05 . Which mean that the Fixed effect model is appropriate for the regression analysis because $\mathrm{H}_{0}$ is rejected and $\mathrm{H}_{\mathrm{A}}$ is accepted.

\subsection{Regression Analysis with Fixed Effect Model Approach}

On the basis of the houseman test, the fixed effect model is appropriate for the final discussion on the hypothesis. Table 3 shows the result of the fixed effect model there are 56 observations; the p-value is zero, which indicate the results are significant. The value of adjusted $R^{2}$ is 0.68 , which indicate that the $68 \%$ change in Tobin's $\mathrm{Q}$ due to the all autonomous and control variables as well as the value of adjusted $R^{2}$ shows that the model is good fit enough (SAJJAD, 2017). The DW value is near to 2 which indicate that there is no high issue of serial auto-correlation in the model (Chatfield, 1998; Durbin \& Watson, 1951; Savin \& White, 1977).

Table 3. Fixed Effect Model

\begin{tabular}{crrrl}
\hline Variable & Coefficient & Std. Error & t-Statistic & Prob. \\
\hline C & -10.69988 & 6.484801 & -1.649993 & 0.1079 \\
AC_MF & -0.225460 & 0.091478 & -2.464648 & 0.0188 \\
AC_SIZE & -0.020177 & 0.121985 & -0.165403 & 0.0696 \\
IND_A & 0.002036 & 0.004481 & 0.454465 & 0.0423 \\
GROWTH & 0.009280 & 0.005291 & 1.754013 & 0.0882 \\
LEV & -0.051894 & 0.085877 & -0.604277 & 0.5496 \\
C_SIZE & 0.562013 & 0.270472 & 2.077896 & 0.0451 \\
BIG4 & -0.037249 & 0.183258 & -0.203262 & 0.8401 \\
\hline
\end{tabular}

EFFECTS SPECIFICATION

Cross-section fixed (dummy variables)

\begin{tabular}{llll}
\hline $\mathrm{R}^{2}$ & 0.796963 & Mean dependent var & 1.397697 \\
Adj. $\mathrm{R}^{2}$ & 0.680942 & S.D. dependent var & 0.525503 \\
S.E. of regression & 0.296832 & Akaike info criterion & 0.688692 \\
Sum squared resid & 3.083814 & Schwarz criterion & 1.448199 \\
Log likelihood & 1.716613 & Hannan-Quinn criter. & 0.983152 \\
F-statistic & 6.869123 & Durbin-Watson stat & 1.564464 \\
P-value & 0.000000 & & \\
\hline
\end{tabular}




\subsection{Results of AC Structure}

Table 3 shows the outcomes of analysis with the fixed effect approach, the AC structure consists of three variables which are AC_MF, AC_SIZE, and IND_A. the result of the fixed effect model designates that AC_MF is negative and statically significant with the Tobin's Q as a proxy for a firms' financial value. The result of this study about AC_MF is not matched with the result of (Sharma, Naiker, \& Lee, 2009) however, the results are up to some limit agree with results of (Greco, 2011). AC_SIZE is negative and insignificant with Tobin's Q (Abbott, Parker, \& Peters, 2004; DeAngelo, 1981). However, the IND_A is having a positive and significant impact on Tobin's Q (Bronson, Carcello, Hollingsworth, \& Neal, 2009; DeZoort \& Salterio, 2001). So there is a need for more research on that, how many meetings should be done in a year? How many independent members should be in an audit committee? This is the consideration for upcoming researchers and contributors.

\subsection{The Result of the Control Variables}

The four control variables are used in this study, the first one is GROWTH which shows the positive effect on Tobin's Q at the level of 5\% it is insignificant but at the level of 10\%, it is statistically significant (Agyemang-Mintah \& Schadewitz, 2018; Sharma et al., 2009). The capital structure (LEV) is negative and insignificant with the company's performance. Company size (C_SIZE) is positive and significant with Tobin's Q as a proxy of the financial performance of the companies at a level of 5\% (Agyemang-Mintah \& Schadewitz, 2018; Mousa \& Saeed, 2017). Last, the dummy variable BIG4 is insignificant with the firms' performance.

\subsection{Discussion on the Hypothesis}

The first hypothesis $\mathrm{H}_{1}$ of study is rejected because it has significantly negative effect on firms' value. The second hypothesis of the study $\mathrm{H}_{2}$ also rejected because there is negtive and insignificant link between AC_MF and firms' value (Madi et al., 2014). The third, hypothesis of the study $\mathrm{H}_{3}$ is accepted because there is a positive and significant affiliation between AC_\%ind.A and firms' value (Madi et al., 2014).

\section{Summary and Conclusions}

The tenacity of this study is to scrutinize the impact of $\mathrm{AC}$ structure on the financial performance of the companies. For this purpose, the researcher collected manual information from the yearly publications of 14 Pakistani cement companies. By using SPSS and EVIEWS the researcher runs different types of the analysis to get the results of the data which was collected from the annual publications of the companies. The empirical results of study reject the hypothesis $\mathrm{H}_{1} \& \mathrm{H}_{2}$ and the third one is accepted $\mathrm{H}_{3}$.

This revision donates to the surviving collected works of the corporate governance (CG) in that this way: the AC structure which exists on AC_SIZE, AC_MF and AC_\%ind. Auditors, how it affects the company's performances. Because the audit committee is the best sentient out of corporate governance, therefore the structure of $\mathrm{AC}$ is valuable to enhance or reduce 
the performance of the AC. So the results indicate that the AC_SIZE and AC_MF have a negative impact on a company's financial performance, while the \%ind. Auditors are positive relationships with Tobin's Q as a proxy for the financial performance of the companies.

For the professionals and policymakers the study state that the appropriate structure of AC is a key factor for success, therefore at the time of AC design, the elements of the AC structure should be considered, how it stimulus the company's performance. The best combination of the AC structure will play a vital role in increasing the company's performance. We can take help from various types of studies and further research on AC and its structure for the best mishmash of AC elements (Klein, 1998; Xie, Davidson III, \& DaDalt, 2003).

This study faces different limitations: the first one is data size is small which produce only 56 observations because time was too short, the second one is data from Pakistani companies and from only one sector so the result may be not widely acceptable on other economy or other sectors. Last but not the least is, the data is manually calculated from annual publications so the chances of error are also prevailing. The researcher suggests some future keys: increase data size, implementation of other sectors and economies. Add new elements in AC structure like Multiple directorships of the members of AC, and financial experience of the members.

\section{Acknowledgment}

First and foremost, I would like to thank God for the strength He gave me to carry out this research work. Secondly, I would like to thank my supervisor Mr. Kamran Ali for the guidance and cooperation he accorded me throughout this research paper. This paper could not have been completed on time without his help and support. Special gratitude also goes to my parents for standing by my side in the quest for education. My brother Tahir Mahmood who provided funds and exceptional support that gave the much-needed confidence and motivation to soldier on even when the going was tough. At the last I would also like to thanks my honorable teacher Dr. Naveed Iqbal Chaudhry for reviewing this paper.

\section{References}

Aanu, O. S., Odianonsen, I. F., \& Foyeke, O. I. (2014). Effectiveness of audit committee and firm financial performance in Nigeria: an empirical analysis. Journal of Accounting and Auditing, 1. https://doi.org/10.5171/2014.301176

Abbott, L. J., Park, Y., \& Parker, S. (2000). The effects of audit committee activity and independence on corporate fraud. Managerial Finance, 26(11), 55-68. https://doi.org/10.1108/03074350010766990

Abbott, L. J., Parker, S., \& Peters, G. F. (2004). Audit committee characteristics and restatements. Auditing: A Journal of Practice \& Theory, 23(1), 69-87. https://doi.org/10.2308/aud.2004.23.1.69 
Abdul Rahman, R., \& Haneem Mohamed Ali, F. (2006). Board, audit committee, culture and earnings management: Malaysian evidence. Managerial Auditing Journal, 21(7), 783-804. https://doi.org/10.1108/02686900610680549

Agrawal, A., \& Knoeber, C. R. (1996). Firm performance and mechanisms to control agency problems between managers and shareholders. Journal of financial and quantitative analysis, 31(3), 377-397. https://doi.org/10.2307/2331397

Agyemang-Mintah, P. (2015). The nomination committee and firm performance: An empirical investigation of UK financial institutions during the pre/post financial crisis. Corporate Board: Role, Duties and Composition, 11(3), 176-190. https://doi.org/10.22495/cbv11i3art14

Agyemang-Mintah, P., \& Schadewitz, H. (2018). Audit committee adoption and firm value: evidence from UK financial institutions. International Journal of Accounting \& Information Management(just-accepted), 00-00. https://doi.org/10.1108/IJAIM-04-2017-0048

Akhtaruddin, M., \& Haron, H. (2010). Board ownership, audit committees' effectiveness and corporate voluntary disclosures. Asian Review of Accounting, 18(1), 68-82. https://doi.org/10.1108/13217341011046015

Aldamen, H., Duncan, K., Kelly, S., McNamara, R., \& Nagel, S. (2012). Audit committee characteristics and firm performance during the global financial crisis. Accounting \& Finance, 52(4), 971-1000. https://doi.org/10.1111/j.1467-629X.2011.00447.x

April, K. A., Bosma, P., \& Deglon, D. A. (2003). IC measurement and reporting: establishing a practice in SA mining. Journal of intellectual capital, 4(2), 165-180. https://doi.org/10.1108/14691930310472794

Arslan, M., Zaman, R., Malik, R. K., \& Mehmood, A. (2014). Impact of CEO Duality and Audit Committee on Firm Performance: A Study of Oil \& Gas Listed Firms of Pakistan. Research Journal of Finance and Accounting, 5(17). https://doi.org/10.2139/ssrn.2515067

Barako, D. G., Hancock, P., \& Izan, H. (2006). Factors influencing voluntary corporate disclosure by Kenyan companies. Corporate Governance: An International Review, 14(2), 107-125. https://doi.org/10.1111/j.1467-8683.2006.00491.x

Bédard, J., \& Gendron, Y. (2010). Strengthening the financial reporting system: Can audit committees deliver? International journal of auditing, 14(2), 174-210. https://doi.org/10.1111/j.1099-1123.2009.00413.x

Beiner, S., Drobetz, W., Schmid, M. M., \& Zimmermann, H. (2006). An integrated framework of corporate governance and firm valuation. European Financial Management, 12(2), 249-283. https://doi.org/10.1111/j.1354-7798.2006.00318.x

Berkman, O., \& Zuta, S. D. (2017). The Impact of Audit Committee Size and Composition on Negative Events in the Life of a Company: The Case of Israel. 
Black, B. S., Jang, H., \& Kim, W. (2006). Does corporate governance predict firms' market values? Evidence from Korea. The Journal of Law, Economics, and Organization, 22(2), 366-413. https://doi.org/10.1093/jleo/ewj018

Botosan, C. A. (1997). Disclosure level and the cost of equity capital. Accounting review, 323-349.

Bradbury, M., Mak, Y. T., \& Tan, S. (2006). Board characteristics, audit committee characteristics and abnormal accruals. Pacific accounting review, 18(2), 47-68. https://doi.org/10.1108/01140580610732813

Bronson, S. N., Carcello, J. V., Hollingsworth, C. W., \& Neal, T. L. (2009). Are fully independent audit committees really necessary? Journal of Accounting and Public Policy, 28(4), 265-280. https://doi.org/10.1016/j.jaccpubpol.2009.06.001

Carcello, J. V., \& Neal, T. L. (2003). Audit committee independence and disclosure: Choice for financially distressed firms. Corporate Governance: An International Review, 11(4), 289-299. https://doi.org/10.1111/1467-8683.00327

Carcello, J. V., Hermanson, D. R., Neal, T. L., \& Riley, R. A. (2002). Board characteristics and audit fees. Contemporary accounting research, 19(3), 365-384. https://doi.org/10.1506/CHWK-GMQ0-MLKE-K03V

Chatfield, C. (1998). Durbin-Watson test. Encyclopedia of Biostatistics.

Chenhall, R. H., \& Moers, F. (2007). The issue of endogeneity within theory-based, quantitative management accounting research. European Accounting Review, 16(1), 173-196. https://doi.org/10.1080/09638180701265937

Choi, J.-H., Jeon, K.-A., \& Park, J.-I. (2004). The role of audit committees in decreasing earnings management: Korean evidence. International Journal of Accounting, Auditing and Performance Evaluation, 1(1), 37-60. https://doi.org/10.1504/IJAAPE.2004.004142

Chung, K. H., \& Pruitt, S. W. (1994). A simple approximation of Tobin's q. Financial management, 70-74. https://doi.org/10.2307/3665623

DeAngelo, L. E. (1981). Auditor size and audit quality. Journal of accounting and economics, 3(3), 183-199. https://doi.org/10.1016/0165-4101(81)90002-1

DeFond, M. L., Hann, R. N., \& Hu, X. (2005). Does the market value financial expertise on audit committees of boards of directors? Journal of Accounting research, 43(2), 153-193. https://doi.org/10.1111/j.1475-679x.2005.00166.x

DeZoort, F. T., \& Salterio, S. E. (2001). The effects of corporate governance experience and financial-reporting and audit knowledge on audit committee members' judgments. Auditing: A Journal of Practice \& Theory, 20(2), 31-47. https://doi.org/10.2308/aud.2001.20.2.31

Dhaliwal, D., Naiker, V., \& Navissi, F. (2010). The association between accruals quality and the characteristics of accounting experts and mix of expertise on audit committees. 
Contemporary accounting research, 27(3),

787-827.

https://doi.org/10.1111/j.1911-3846.2010.01027.x

Durbin, J., \& Watson, G. S. (1951). Testing for serial correlation in least squares regression. II. Biometrika, 38(1/2), 159-177. https://doi.org/10.1093/biomet/38.1-2.159

Durnev, A., \& Kim, E. (2005). To steal or not to steal: Firm attributes, legal environment, and valuation. The journal of finance, 60(3), 1461-1493. https://doi.org/10.1111/j.1540-6261.2005.00767.x

Fama, E., \& Jensen, M. C. (1983). Separation of ownership and control. Journal of Law and Economics, 26, 1983a. https://doi.org/10.1086/467037

Felo, A. J., Krishnamurthy, S., \& Solieri, S. A. (2003). Audit committee characteristics and the perceived quality of financial reporting: an empirical analysis.

Ferreira, I. (2008). The effect of audit committee composition and structure on the performance of audit committees. Meditari: Research Journal of the School of Accounting Sciences, 16(2), 89-106. https://doi.org/10.1108/10222529200800014

Firer, C., \& Meth, G. (1986). Information disclosure in annual reports in South Africa. Omega, 14(5), 373-382. https://doi.org/10.1016/0305-0483(86)90078-2

Gompers, P., Ishii, J., \& Metrick, A. (2003). Corporate governance and equity prices. The $\begin{array}{llll}\text { quarterly journal of economics, } & 118(1),\end{array}$ https://doi.org/10.1162/00335530360535162

Greco, G. (2011). Determinants of board and audit committee meeting frequency: Evidence from Italian companies. Managerial Auditing Journal, 26(3), 208-229. https://doi.org/10.1108/02686901111113172

Guest, P. M. (2009). The impact of board size on firm performance: evidence from the UK. The European Journal of Finance, 15(4), 385-404. https://doi.org/10.1080/13518470802466121

Hair, J. F., Black, W. C., Babin, B. J., Anderson, R. E., \& Tatham, R. L. (1998). Multivariate data analysis (Vol. 5): Prentice hall Upper Saddle River, NJ.

Haniffa, R., \& Hudaib, M. (2006). Corporate governance structure and performance of Malaysian listed companies. Journal of Business Finance \& Accounting, 33(7 - 8), 1034-1062. https://doi.org/10.1111/j.1468-5957.2006.00594.x

Henry, D. (2008). Corporate governance structure and the valuation of Australian firms: is there value in ticking the boxes? Journal of Business Finance \& Accounting, 35(7 - 8), 912-942. https://doi.org/10.1111/j.1468-5957.2008.02100.x

Ho, C.-A., \& Williams, S. M. (2003). International comparative analysis of the association between board structure and the efficiency of value added by a firm from its physical capital and intellectual capital resources. The International Journal of Accounting, 38(4), 465-491. https://doi.org/10.1016/j.intacc.2003.09.001 
Karamanou, I., \& Vafeas, N. (2005). The association between corporate boards, audit committees, and management earnings forecasts: An empirical analysis. Journal of Accounting research, 43(3), 453-486. https://doi.org/10.1111/j.1475-679X.2005.00177.x

Khosa, A. (2017). Independent directors and firm value of group-affiliated firms. International Journal of Accounting \& Information Management, 25(2), 217-236. https://doi.org/10.1108/IJAIM-08-2016-0076

Klapper, L. F., \& Love, I. (2004). Corporate governance, investor protection, and performance in emerging markets. Journal of Corporate Finance, 10(5), 703-728. https://doi.org/10.1016/S0929-1199(03)00046-4

Klein, A. (1998). Firm performance and board committee structure. The Journal of Law and Economics, 41(1), 275-304. https://doi.org/10.1086/467391

Krause, T. A., \& Tse, Y. (2016). Risk management and firm value: recent theory and evidence. International Journal of Accounting and Information Management, 24(1), 56-81. https://doi.org/10.1108/IJAIM-05-2015-0027

Li, J., Mangena, M., \& Pike, R. (2012). The effect of audit committee characteristics on intellectual capital disclosure. The British Accounting Review, 44(2), 98-110. https://doi.org/10.1016/j.bar.2012.03.003

Madi, H. K., Ishak, Z., \& Manaf, N. A. A. (2014). The impact of audit committee characteristics on corporate voluntary disclosure. Procedia-social and behavioral sciences, 164, 486-492. https://doi.org/10.1016/j.sbspro.2014.11.106

Mangena, M., \& Chamisa, E. (2008). Corporate governance and incidences of listing suspension by the JSE Securities Exchange of South Africa: An empirical analysis. The $\begin{array}{llll}\text { International Journal of Accounting, } & \text { 43(1), }\end{array}$ https://doi.org/10.1016/j.intacc.2008.01.002

Modigliani, F., \& Miller, M. H. (1963). Corporate income taxes and the cost of capital: a correction. The American economic review, 53(3), 433-443.

Mousa, H. A. M., \& Saeed, A. M. M. M. (2017). The impact of board independence on accounting-based performance: Evidence from Saudi Arabia and Bahrain. Journal of Economic and Administrative Sciences, 33(2), 114-130. https://doi.org/10.1108/JEAS-03-2017-0012

Munisi, G., \& Randøy, T. (2013). Corporate governance and company performance across Sub-Saharan African countries. Journal of Economics and Business, 70, 92-110. https://doi.org/10.1016/j.jeconbus.2013.08.003

Ntim, C. G. (2013). Corporate ownership and market valuation in South Africa: Uncovering the effects of shareholdings by different groups of corporate insiders and outsiders. International Journal of Business Governance and Ethics, 8(3), 242-264. https://doi.org/10.1504/IJBGE.2013.057378 


\section{MInstitute Macrothink}

Journal of Corporate Governance Research ISSN 1948-4658

Othman, R., Ishak, I. F., Arif, S. M. M., \& Aris, N. A. (2014). Influence of audit committee characteristics on voluntary ethics disclosure. Procedia-social and behavioral sciences, 145, 330-342. https://doi.org/10.1016/j.sbspro.2014.06.042

Persons, O. (2009). Audit committee characteristics and earlier voluntary ethics disclosure among fraud and no-fraud firms. International Journal of Disclosure and Governance, 6(4), 284-297. https://doi.org/10.1057/jdg.2008.29

Qaiser Rafique, Y., \& Al Mamun, A. (2015). The impact of audit committee characteristics on firm performance: Evidence from Pakistan. New Zealand Journal of Applied Business Research, 13(1), 35.

SAJJAD, R. (2017). Impact Of Characteristics Of Board On Earnings Management Of The Firms: Evidence From Pakistan Stock Exchange. Capital University.

Savin, N. E., \& White, K. J. (1977). The Durbin-Watson test for serial correlation with extreme sample sizes or many regressors. Econometrica: Journal of the Econometric Society, 1989-1996. https://doi.org/10.2307/1914122

Sharma, V., Naiker, V., \& Lee, B. (2009). Determinants of audit committee meeting frequency: Evidence from a voluntary governance system. Accounting Horizons, 23(3), 245-263. https://doi.org/10.2308/acch.2009.23.3.245

Van Der Zahn, J. W. M., \& Tower, G. (2004). Audit committee features and earnings management: further evidence from Singapore. International Journal of Business Governance and Ethics, 1(2-3), 233-258. https://doi.org/10.1504/IJBGE.2004.005257

Waresul Karim, A., van Zijl, T., \& Mollah, S. (2013). Impact of board ownership, CEO-Chair duality and foreign equity participation on auditor quality choice of IPO companies: evidence from an emerging market. International Journal of Accounting \& Information Management, 21(2), 148-169. https://doi.org/10.1108/18347641311312285

Xie, B., Davidson III, W. N., \& DaDalt, P. J. (2003). Earnings management and corporate governance: the role of the board and the audit committee. Journal of Corporate Finance, 9(3), 295-316. https://doi.org/10.1016/S0929-1199(02)00006-8

Yermack, D. (1996). Higher market valuation of companies with a small board of directors. Journal of Financial Economics, $40(2), \quad 185-211$. https://doi.org/10.1016/0304-405X(95)00844-5

Zagorchev, A., \& Gao, L. (2015). Corporate governance and performance of financial institutions. Journal of Economics and Business, 82, 17-41. https://doi.org/10.1016/j.jeconbus.2015.04.004

Zha, H. (2006). The auditing committee and earnings quality: empirical evidence from Chinese securities market. Auditing Research, 6, 50-57. 


\section{Appendix}

\section{Simple regression model:}

$$
\begin{aligned}
\text { Tobin's }_{i, t}= & \boldsymbol{\alpha}_{0}+\boldsymbol{\alpha}_{1} \text { AC.Size }_{i, t}+\boldsymbol{\alpha}_{2} A C \cdot M F_{i, t}+\boldsymbol{\alpha}_{3} A C . \% \text { Ind. } A_{i, t} \\
& +\boldsymbol{\beta}_{1} \text { Growth }_{i, t}+\boldsymbol{\beta}_{2} \text { Lev }_{i, t}+\boldsymbol{\beta}_{3} \text { C.Size } e_{i, t}+\boldsymbol{\beta}_{4} \text { Big }_{i, t}+\varepsilon_{i, t}
\end{aligned}
$$

\begin{tabular}{|c|c|}
\hline \multicolumn{2}{|c|}{ Dependent variables: } \\
\hline Tobin's Q & $\begin{array}{l}\text { Tobin's Q is premeditated as the book value of total assets plus equity market } \\
\text { value minus equity book value divide by assets total value. (Beiner et al., 2006; } \\
\text { Chung \& Pruitt, 1994) }\end{array}$ \\
\hline \multicolumn{2}{|c|}{ Independent variables: } \\
\hline AC SIZE & $\begin{array}{l}\text { AC size is the sum of all members of the audit committee. (Berkman \& Zuta, } \\
\text { 2017; Madi et al., 2014) }\end{array}$ \\
\hline AC. MF & $\begin{array}{l}\text { AC meeting frequency is the sum of all meeting held by audit committee } \\
\text { during the year. (Berkman \& Zuta, 2017; Madi et al., 2014) }\end{array}$ \\
\hline $\begin{array}{l}\text { AC \%ind. } \\
\text { A }\end{array}$ & $\begin{array}{l}\text { Percentage of independent auditors in the audit committee. (Berkman \& Zuta, } \\
\text { 2017) }\end{array}$ \\
\hline \multicolumn{2}{|c|}{ Control variables: } \\
\hline Growth & $\begin{array}{l}\text { Growth is calculated as sale growth ratio divide by assets growth ratio. Which } \\
\text { companies have higher opportunities for investment growing much faster, with } \\
\text { growing much faster that's companies receive better performance and high } \\
\text { valuation (Durnev \& Kim, 2005; Klapper \& Love, 2004). }\end{array}$ \\
\hline LEV & $\begin{array}{l}\text { LEV used for a capital structure which is calculated as } \% \text { of total debts divide } \\
\text { by } \% \text { of total assets. The capital structure may have an effect on companies } \\
\text { success (Modigliani \& Miller, 1963). }\end{array}$ \\
\hline C. Size & $\begin{array}{l}\text { Company size is the natural log of the total assets. In large companies, there is } \\
\text { a bigger volume of the transaction under audit committee (Waresul Karim et } \\
\text { al., 2013). }\end{array}$ \\
\hline Big4 & $\begin{array}{l}\text { Big four is the dummy variable: a company audit by big four audit companies } \\
\text { including A.F Ferguson \& Co., KPMG, Ernst \&Young, and Deloitte touch. } \\
\text { Assign } 1 \text { and if not then } 0 \text {. }\end{array}$ \\
\hline
\end{tabular}

Table 1: Summary of variables and explanation.

\section{Copyright Disclaimer}

Copyright for this article is retained by the author(s), with first publication rights granted to the journal.

This is an open-access article distributed under the terms and conditions of the Creative Commons Attribution license (http://creativecommons.org/licenses/by/3.0/). 